Volume 1 Nomor 2

Agustus 2021

\title{
PENGARUH CORPORATE SOCIAL RESPONSIBILITY, BEBAN PAJAK TANGGUHAN DAN TAX PLANNING TERHADAP MANAJEMEN LABA
}

\author{
Syamsul Asmedi ${ }^{1}$, Rizky Wulandari ${ }^{2}$ \\ ${ }^{1,2}$ Universitas Pamulang \\ asmedie2017@gmail.com
}

\begin{abstract}
ABSTRAK
Penelitian ini bertujuan untuk menguji pengaruh corporate social responsibility, beban pajak tangguhan dan tax planning terhadap manajemen laba . Variabel independen yang digunakan dalam penelitian ini adalah corporate social responsibility, beban pajak tangguhan dan tax planning, Sedangkan variabel dependen dalam penelitian ini adalah manajemen laba. Jenis penelitian yang digunakan dalam penelitian ini adalah data kuantitatif. Sumber data yang digunakan dalam penelitian ini adalah data sekunder. Populasi dalam penelitian ini adalah perusahaan manufaktur sektor industri barang dan konsumsi yang terdaftar di Bursa Efek Indonesia (BEI) selama periode 2014-2018. Penentuan sampel penelitian ini menggunakan metode purposive sampling dan memperoleh sampel penelitian sebanyak 10 perusahaan. Analisis data yang digunakan dalam penelitian ini adalah uji statistik deskripstif, uji asumsi klasik dan uji hipotesis. Hasil penelitian ini menunjukan bahwa corporate social responsibility tidak berpengaruh signifikan terhadap manajemen laba, Beban pajak tangguhan tidak berpengaruh signifikan terhadap manajemen laba dan tax planning berpengaruh signifikan terhadap manajemen laba. Sedangkan secara simultan menunjukkan bahwa corporate social responsibility, beban pajak tangguhan dan tax planning secara bersama-sama berpengaruh signifikan terhadap manajemen laba.
\end{abstract}

Kata Kunci : Corporate Social Responsibility, Beban Pajak Tangguhan, Tax Planning , Manajemen Laba.

\section{ABSTRACT}

This study aims to examine the effect of corporate social responsibility, deferred tax burden and tax planning on earnings management. The independent variables used in this study are corporate social responsibility, deferred tax burden and tax planning, while the dependent variable in this study is earnings management. The type of research used in this research is quantitative data. Sources of data used in this study is secondary data. The population in this study are manufacturing companies in the consumer goods and industrial sector listed on the Indonesia Stock Exchange (IDX) during the 2014-2018 period. Determination of the sample of this study using purposive sampling method and obtained a research sample of 10 companies. Analysis of the data used in this study is descriptive statistical test, classical assumption test and hypothesis testing. The analytical method used is a hypothesis with the help of SPSS version 25 software. The results of this study indicate that corporate social responsibility has no significant effect on earnings management, deferred tax expense has no significant effect on earnings management and tax planning has a significant effect on earnings management. Meanwhile, simultaneously shows that corporate social responsibility, deferred tax expense and tax planning together have a significant effect on earnings management.

Keywords: Corporate Social Responsibility, Deferred Tax Burden, Tax Planning, Earnings Management. 
PENDAHULUAN

Kondisi perkembangan ekonomi global saat ini menuntut perusahaan untuk dapat memaksimalkan

fungsi-fungsi manajemennya dalam rangka mencapai tujuannya. Perusahaan didirikan dengan tujuan utama untuk memperoleh laba sebanyak-banyaknya. Dalam era globalisasi perkembangan dunia semakin meningkat dan menuntut perusahaan untuk selalu mengembangkan strategi dan inovasinya agar dapat bertahan hidup, berkembang dan berdaya saing. Hal tersebut merupakan peluang sekaligus menjadi ancaman bagi perusahaan-perusahaan yang ada di Indonesia baik itu perusahaan jasa, perusahaan dagang maupun perusahaan manufaktur.

Pihak manajemen sebagai pengelola perusahaan secara langsung tentu ingin memperoleh laba yang tinggi, hal ini tentu akan berpengaruh langsung pada bonus yang akan diterima pihak manajemen karena semakin tinggi laba yang dicapai perusahaan maka akan tinggi pula bonus yang diperoleh pihak manajemen. Di sisi lainnya pengestimasian kekuatan laba (earnings power) dalam memperkirakan risiko investasi maupun kredit dari informasi laba tersebut akan dapat membantu para pemilik (stakeholders) sehingga pihak manajemen bertanggung jawab akan informasi laba tersebut yang mana kinerjanya diukur melalui pencapaian laba yang diperoleh.

Manajemen laba dapat diukur dengan menggunakan manajemen laba akrual, manajemen laba riil dan manajemen laba terintegrasi. Manajemen laba akrual meliputi short term discretionar model dan long term discretionary. Kusuma (2006) mengatakan model short term accruals merupakan cara manajemen laba yang berkaitan dengan melalui aktiva dan hutang lancar, biasanya waktu yang dilakukan adalah pada kuartal pertama atau satu tahun buku..

Fenomena manajemen laba yang pernah terjadi ialah yang dilakukan oleh PT Toshiba. Pimpinan puncak PT Toshiba Corporation terlibat secara "sistematis" dalam skandal penggelembungan keuntungan perusahaan sebesar 1,2 miliar dollar AS selama beberapa tahun (www.kompas.com oleh Yoga Sukmana, 21 Juli 2015). Berdasarkan hasil investigasi, diketahui tindakan pengelembungan laba tersebut dilakukan karena PT Toshiba telah gagal mencapai target keuntungan ditambah lagi krisis global yang melanda pada waktu itu. Tindakan pengelembungan laba tersebut membuat CEO Hisao Tanaka memutuskan untuk mengundurkan diri, selain itu nama Toshiba juga dihapus dari indeks saham dan penurunan penjualan yang signifikan (Intergrity-Indonesia.com, 14 September 2017). Dari kasus tersebut dapat disimpulkan bahwa tidakan manajemen laba pada akhirnya merugikan perusahaan itu sendiri di masa depan.

Sejalan dengan pernyataan Kusuma et al (2014:1), kegiatan CSR ini dimanfaatkan manajemen sebagai tameng atau strategi mempertahankan diri (entrenchment strategy) dari tindakannya dalam mengelola laba perusahaan agar reputasi perusahaan tetap terjaga baik dan melindungi karir manajer secara pribadi.

Pajak merupakan salah satu sumber penerimaan negara, termasuk Indonesia yang mengandalkan penerimaan pajak sebagai sumber penerimaan negara yang utama (Irianto, 2010). Salah satu sektor pajak yang paling besar diperoleh Negara adalah pajak penghasilan. Untuk akuntansi pajak penghasilan, setiap perusahaan dalam membuat laporan keuangan diharuskan untuk mengikuti kaidah Pernyataan Standar Akuntansi Keuangan (PSAK) agar dapat menghasilkan laporan keuangan yang kredibel dan informatif kepada investor dan kreditor. Selain itu, perusahaan juga diharuskan untuk menyusun laporan laba rugi berdasarkan aturan perpajakan.

Berdasarkan latar belakang diatas, maka penulis tertarik untuk melakukan suatu penelitian dengan judul "Pengaruh Corporate Social Responsibility, Beban Pajak Tangguhan, dan Tax Planning Terhadap Manajemen Laba. (Studi Empiris Pada Perusahaan Manufaktur 
Sektor Industri Barang dan Konsumsi yang Terdaftar di Bursa Efek Indonesia Tahun 2014-2018)"

\section{TINJAUAN PUSTAKA}

Menurut Jensen dan Meckling (dalam Luayyi, 2012) mengungkapkan bahwa hubungan keagenan adalah sebuah kontrak antara manajer (agent) dengan investor (principal). Sehingga konflik kepentingan antara pemilik dan agen terjadi karena kemungkinan agen tidak selalu berbuat sesuai dengan kepentingan principal, yang kemudian memicu biaya keagenan (agency cost).

Teori Keagenan diartikan sebagai hubungan keagenan yang timbul pada saat pemilik perusahaan (principal) memberikan wewenang kepada seseorang yang profesional (agent) untuk mengelola perusahaannya yang diberikan kewenangan untuk mengambil setiap tindakan dan keputusan terkait pengembangan perusahaan tersebut Jensen dan Meckling (dalam Andrean, 2018).

\section{Manajemen Laba (Y)}

Menurut Terry (dalam Nisak dan Heri, 2017 ) mengkaji "management is a distinct process consisting of planning, organizing, actuating, and controlling, performed to determine and accomplish stated objectives by the use of human being and other resources". Manajemen adalah suatu proses yang khas terdiri atas perencanaan, pengorganisasian, penggerakan dan pengontrolan guna mencapai tujuan yang telah ditetapkan dengan menggunakan sumber daya manusia dan sumber daya lain

Menurut Astutik dan Titik (dalam Irsan dan Suryani, 2018) Manajemen laba juga merupakan tindakan manajer untuk meningkatkan (mengurangi) laba yang dilaporkan saat ini atas suatu unit usaha dimana manajer bertanggung jawab, tanpa mengakibatkan peningkatan (penurunan) profitabilitas ekonomi jangka panjang unit usaha tersebut.

\section{Corporate Social Responsibility (X1)}

Menurut Rahmawati (dalam Ghifari \& Sugeng, 2018) Corporate Social
Responsibility

adalah:

"Pertanggungjawaban Sosial Perusahaan atau Corporate Social Responsibility (CSR) adalah mekanisme bagi suatu organisasi untuk secara sukarela mengintegrasikan perhatian terhadap lingkungan dan sosial ke dalam tanggung jawab operasinya dan interaksinya dengan stakeholders, yang melebihi tanggung jawab organisasi di bidang hukum."

CSR juga dapat digunakan perusahaan agar lebih unggul dari pesaing dalam hal mendapatkan keuntungan. Begitu sebuah perusahaan dalam suatu industri telah berhasil menerapkan kebijakan CSR, perusahaan pesaing mungkin terpaksa untuk terlibat juga dalam aktivitas CSR. Apabila perusahaan pesaing tidak menerapkan CSR, maka perusahaan pesaing tersebut terancam kehilangan loyalitas konsumen. Di sisi lain, beberapa perusahaan yang terlibat dalam CSR hanya karena mereka percaya bahwa hal tersebut benar untuk dilakukan.

\section{METODOLOGI PENELITIAN Jenis dan Sumber Penelitian}

Penelitian ini menggunakan penelitian kuantitatif karena penelitian ini disajikan dalam angka-angka atau data yang diangkakan. Penelitian kuantitatif yaitu penelitian yang berlandaskan pada filsafat positivisme, digunakan untuk meneliti pada populasi atau sampel tertentu, teknik pengambilan sampel pada umumnya dilakukan secara random, pengumpulan data menggunakan instrumen penelitian, analisis data bersifat kuantitatif/statistik dengan tujuan untuk menguji hipotesis yang telah ditetapkan (Sugiyono, 2017:8).

Sumber data dalam penelitian ini adalah data sekunder. Data sekunder adalah data yang diperoleh atau dikumpulkan dari sumber-sumber yang telah ada. Penelitian ini menggunakan data sekunder yang diperoleh dari laporan tahuan dan laporan keuangan perusahaan yang terdaftar di Bursa Efek Indonesia (BEI) pada tahun 2014 sampai tahun 2018. Data diperoleh dari situs resmi BEI www.idx.co.id. 


\section{Tempat dan Waktu Penelitian}

Peneltian ini menggunakan data laporan keuangan Perusahaan Manufaktur Sektor Industri Barang Konsumsi yang tedaftar di Bursa Efek Indonesia tahun 2014-2018. Dipilihnya BEI sebagai tempat penelitian karena BEI merupakan bursa pertama di Indonesia yang di anggap memiliki data yang lengkap dan telah terorganisasi dengan baik. Untuk mendapatkan laporan keuangan tahunan diperoleh melalui situs resminya Bursa Efek Indonesia yaitu www.idx.co.id.

\section{HASIL PENELITIAN DAN \\ PEMBAHASAN \\ Hasil Penelitian \\ Uji Normalitas}

Hasil uji normalitas juga dapat dilihat pada grafik normal probability plot (p-plot) of regression yang membandingkan distribusi kumulatif dari distribusi normal. Distribusi normal akan membentuk satu garis lurus diagonal, plotting, dan residual yang akan dibandingkan dengan garis diagonal. Data dapat dikatakan normal jika data atau titik-titik tersebar disekitar garis diagoanal dan penyebarannya mengikuti garis diagonal (Ghozali, 2016:170). Hasil normal probability plot dapat dilihat dibawah ini :

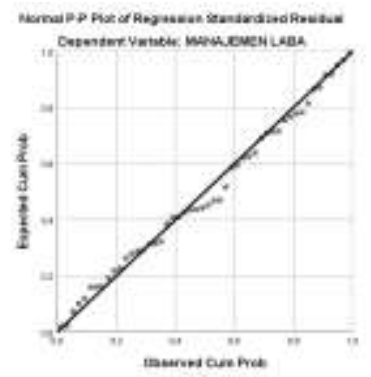

Dengan melihat tampilan uji normalitas gambar 4.1 gambar grafik normal probability plot (p-plot) menunjukkan titik menyebar disekitar garis diagonal dan penyebarannya mengikuti dan mendekati arah garis digonal. Hal ini menunjukkan bahwa data dalam penelitian ini berdistribusi normal, sehingga dapat disimpulkan bahwa model regresi ini memenuhi asumsi normalitas.

\section{Uji Multikolinearitas}

Pada tabel 4.3, menunjukan bahwa model regresi penelitian ini tidak terjadi uji multikolinearitas karena masing-masing variabel bebas yaitu Corporate Social Responsibility $\left(\mathrm{X}_{1}\right), \quad$ Beban Pajak Tangguhan $\left(\mathrm{X}_{2}\right)$ dan Tax Planning $\left(\mathrm{X}_{3}\right)$ memiliki nilai tolerance lebih besar dari > 0,10 yaitu $X_{1} 0,896, X_{2} 0,946, X_{3} 0,880$ dan memiliki nilai VIF lebih kecil dari < 10,00 yaitu $\mathrm{X}_{1} 1,117, \mathrm{X}_{2}$ 1,057, $\mathrm{X}_{3}$ 1,136.ji

\section{Heteroskedasitas}

Pada tabel 4.4 diatas menunjukan hasil bahwa nilai signifikan variabel independen corporate social responsibility sebesar 0,319 , beban pajak tangguhan sebesar 0,346 dan tax planning sebesar 0,158. Karena nilai signifikan diatas tingkat kepercayaan 5\% $(\alpha=0,05)$, maka model regresi tidak terjadi heteroskedastisitas.

\section{Uji Autokorelasi}

Pada tabel 4.5 nilai Durbin-Watson menunjukan nilai sebesar 1,446 atau dapat dikatakan memenuhi asumsi yang ke dua yaitu nilai terletak diantara -2 sampai +2 yaitu dimana nilai tersebut $-2<1,446<+2$ sehingga dapat disimpulkan bahwa tidak ada autokorelasi pada data dalam penelitian ini.

\section{Uji Hipotesis}

\section{Analisis Regresi Linear Berganda}

Pada tabel 4.6 hasil yang telah diperoleh dari koefesien regresi maka dapat dibuat suatu persamaan regresi sebagai berikut:

$Y=-0,600+0,025 X_{1}+0,886 X_{2}+0,865 X_{3}$

Berdasarkan persamaan diatas maka koefesien - koefesien linear berganda dapat diartikan sebagai berikut :

1. Nilai konstanta atau $\alpha=-0,600$ mempunyai arti bahwa jika variabel corporate social responsibility (X1), beban pajak tangguhan (X2) dan tax planning (X3) sama dengan nol, maka manajemen laba tahun 2014-2018 pada perusahaan manufaktur sektor industri barang dan konsumsi adalah sebesar 0,600 .

2. Koefesien regresi $\beta 1$ corporate social responsibility (X1) sebesar 0,025 menunjukan bahwa apabila setiap 
penambahan variabel corporate social responsibility 1 dengan asumsi variabel independen variabel lainnya adalah nol, maka manajemen laba mengalami penurunan sebesar $0,025 \%$. Hal tersebut menunjukan bahwa koefisien bernilai positif artinya terjadi hubungan positif antara corporate social responsibility terhadap manajemen laba.

3. Koefesien regresi $\beta 2$ Beban Pajak Tangguhan (X2) sebesar 0,886 menunjukan bahwa apabila setiap penambahan variabel Beban Pajak Tangguhan 1 dengan asumsi variabel independen variabel lainnya adalah nol, maka manajemen laba mengalami kenaikan sebesar $0,886 \%$. Hal tersebut menunjukan bahwa koefisien bernilai positif artinya terjadi hubungan positif antara beban pajak tangguhan terhadap manajemen laba.

4. Koefesien regresi $\beta 3$ Tax Planning (X3) sebesar 0,865 menunjukan bahwa apabila setiap penambahan variabel Tax Planning 1 dengan asumsi variabel independen variabel lainnya adalah nol, maka manajemen laba mengalami kenaikan sebesar $0,865 \%$. Hal tersebut menunjukan bahwa koefisien bernilai positif artinya terjadi hubungan positif antara tax planning terhadap manajemen laba.

\section{Koefisien Determinasi $\left(\mathbf{R}^{\mathbf{2}}\right)$}

Pada tabel 4.7 hasil yang dapat diketahui bahwa nilai koefisien determinasi $\left(\mathrm{R}^{2}\right)$ sebesar 0,195 atau 19,5\%. Maka dapat disimpulkan bahwa variabel corporate social respnsibility $\left(\mathrm{X}_{1}\right)$ beban pajak tangguhan $\left(\mathrm{X}_{2}\right)$ dan tax planning $\left(\mathrm{X}_{3}\right)$ berpengaruh terhadap variabel manajemen laba (Y) sebesar 19,5\% (rendah), sedangkan sisanya sebesar $80,5 \%$ dapat dijelaskan oleh faktor-faktor lain di luar dari pembahasan dalam penelitian ini.

Pengaruh Corporate Social Responsibility, Beban Pajak Tangguhan dan Tax Planning Terhadap Manajemen Laba (H1)

Penelitian ini menguji pengaruh corporate social responsibility, beban pajak tangguhan dan tax planning terhadap manajemen laba berdasarkan tabel 4.10 diatas, diketahui nilai $\mathrm{F}$ hitung $>\mathrm{F}$ tabel atau $(4,961>2,80)$ hal ini diperkuat dengan nilai probability signifikansi $(0,005<0,05)$ artinya berpengaruh atau diterima. Untuk itu hipotesis keempat $\left(\mathrm{H}_{4}\right)$ yang menyatakan bahwa berpengaruh variabel independen corporate social responsibility $\left(\mathrm{X}_{1}\right)$, beban pajak tangguhan $\left(\mathrm{X}_{2}\right)$ dan tax planning $\left(\mathrm{X}_{3}\right)$ secara simultan terhadap variabel dependen manajemen laba (Y) pada perusahaan manufaktur sektor industri barang dan konsumsi yang terdaftar di Bursa Efek Indonesia (BEI) periode tahun 2014-2018.

\section{Pengaruh Corporate Social Responsibility Terhadap Manajemen Laba $\left(\mathrm{H}_{2}\right)$}

Pada tabel 4.10 hasil dari pengujian diperoleh nilai $\mathrm{t}$ hitung dari variabel independen Corporate Social Responsibility sebesar 0,341 dimana lebih kecil dari nilai $\mathrm{t}_{\text {tabel }} 2,01174$, artinya $\mathrm{H} 1$ ditolak. Hal ini diperkuat dengan nilai probability signifikansi $(0,734>0,05)$ artinya tidak berpengaruh atau ditolak. Untuk itu hipotesis pertama $\left(\mathrm{H}_{1}\right)$ yang menyatakan bahwa tidak berpengaruh variabel independen Corporate Social Responsibility $\left(\mathrm{X}_{1}\right)$ signifikan terhadap variabel dependen manajemen laba (Y) pada perusahaan manufaktur sektor industri barang dan konsumsi yang terdaftar di Bursa Efek Indonesia periode tahun 2014-2018.

Hal ini bertolak belakang dengan penelitian yang dilakukan oleh Dewi Kusuma Wardhani dan Desifa Kurnia Santi (2018) yang menyatakan bahwa corporate social responsibility berpengaruh terhadap manajemen laba.

Pengaruh Beban Pajak Tangguhan Terhadap Manajemen Laba $\left(\mathrm{H}_{3}\right)$

Pada tabel 4.10 hasil dari pengujian diperoleh nilai $\mathrm{t}$ hitung dari variabel independen beban pajak tangguhan sebesar 0,828 dimana lebih kecil dari nilai $t_{\text {tabel }}$ 2,01174, artinya $\mathrm{H} 2$ ditolak. Hal ini diperkuat dengan nilai probability signifikansi $(0,412>0,05)$ artinya tidak berpengaruh atau ditolak. Untuk itu hipotesis kedua $\left(\mathrm{H}_{2}\right)$ yang menyatakan 
bahwa tidak berpengaruh variabel independen beban pajak tangguhan $\left(\mathrm{X}_{2}\right)$ signifikan terhadap variabel dependen manajemen laba (Y) pada perusahaan manufaktur sektor industri barang dan konsumsi yang terdaftar di Bursa Efek Indonesia periode tahun 2014-2018.

Hasil penelitian ini sejalan dengan penelitian ynag dilakukan oleh Fransiska Nicolata (2018) dan Budy et al (2016) yang membuktikan bahwa beban pajak tangguhan tidak memiliki pengaruh signifikan terhadap manajemen laba untuk menghindari kerugian. Beban pajak tangguhan timbul akibat perbedaan temporer antara laba akuntansi dan laba fiskal. Perbedaan antara laporan keuangan akuntansi dan fiskal disebakan dalam penyusunan laporan keuangan, standar akuntansi lebih memberikan keleluasan bagi manajemen untuk menentukan prinsip dan asumsi akuntansi dibandingkan yang diperbolehkan menurut pajak. Hal ini membuat manajemen memanfaatkan celah untuk melakukan manipulasi besarnya beban pajak tangguhan yang dimilikinya. Mengukur keleluasaan manajer beban pajak tangguhan lebih baik sebab peraturan akuntansi memberikanlebih banyak keleluasaan disbanding peraturan pajak. Besarnya jumlah beban pajak tangguhan mengurangi laba perusahaan sehingga mengurangi besarnya pajak yang harus dibayarkan.

\section{Pengaruh Tax Planning Terhadap Manajemen Laba $\left(\mathrm{H}_{4}\right)$}

Pada tabel 4.10 hasil dari pengujian diperoleh nilai $\mathrm{t}$ hitung dari variabel independen tax planning sebesar 3,781 dimana lebih besar dari nilai $t_{\text {tabel }} 2,01174$, artinya $\mathrm{H} 3$ diterima. Hal ini diperkuat dengan nilai probability signifikansi $(0,000$ $<0,05)$ artinya berpengaruh. Untuk itu hipotesis ketiga $\left(\mathrm{H}_{3}\right)$ yang menyatakan bahwa berpengaruh variabel independen tax planning $\left(\mathrm{X}_{3}\right)$ signifikan terhadap variabel dependen manajemen laba (Y) pada perusahaan manufaktur sektor industri barang dan konsumsi yang terdaftar di Bursa Efek Indonesia periode tahun 2014-2018.
Hasil penelitian ini konsisten dengan penelitian yang dilakukan oleh Dewa Ketut dan Made Gede (2016) yang menyatakan bahwa tax planning berpengaruh signifikan terhadap manajemen laba. Jika semakin tinggi tingkat tax planning yang dilakukan perusahan maka semakin besar peluang perusahaan melakukan manajemen laba, begitu pula sebaliknya. Selain itu, tax planning digunakan oleh perusahaan untuk meminimalkan pembayaran pajak perusahaan sehingga perusahaan mendapat keuntungan pajak.

\section{Kesimpulan}

1. Berdasarkan hasil uji $F$ atau secara simultan, dari variabel corporate social responsibility, beban pajak tangguhan, dan tax planning terhadap manajemen laba, diketahui nilai $\mathrm{F}$ hitung $>\mathrm{F}$ tabel atau $(4,961>2,80)$ hal ini diperkuat dengan nilai probability signifikansi $(0,005<0,05)$ artinya berpengaruh atau diterima. Untuk itu hipotesis pertama $\left(\mathrm{H}_{1}\right)$ yang menyatakan bahwa berpengaruh variabel independen corporate social responsibility $\left(\mathrm{X}_{1}\right)$, beban pajak tangguhan $\left(\mathrm{X}_{2}\right)$ dan tax planning (X3) secara simultan terhadap variabel dependen manajemen laba (Y) pada perusahaan manufaktur sektor industri dan barang konsumsi yang terdaftar di Bursa Efek Indonesia (BEI) periode tahun 2014-2018.

2. Berdasarkan uji t secara parsial, dari variabel corporate social responsibility terhadap manajemen laba, diketahui nilai $\mathrm{t}$ hitung $<\mathrm{t}$ tabel atau $(0,341<$ 2,01174) hal ini diperkuat dengan nilai probability signifikansi $(0,734>0,05)$ artinya tidak berpengaruh atau ditolak. Untuk itu hipotesis kedua (H2) yang menyatakan bahwa tidak berpengaruh variabel independen corporate social responsibility $\left(\mathrm{X}_{1}\right)$ signifikan terhadap variabel dependen manajemen laba $(\mathrm{Y})$ pada perusahaan manufaktur sektor industri barang dan konsumsi yang terdaftar di Bursa Efek Indonesia (BEI) periode tahun 2014-2018. 
3. Berdasarkan hasil uji $\mathrm{t}$ atau secara parsial, dari variabel beban pajak tangguhan terhadap manajemen laba, diketahui nilai $\mathrm{t}$ hitung $<\mathrm{t}_{\text {tabel }}$ atau ( $0,828<2,01174)$ hal ini diperkuat dengan nilai probability signifikansi $(0,412>0,05)$ artinya tidak berpengaruh atau ditolak. Untuk itu hipotesis ketiga $(\mathrm{H} 3)$ yang menyatakan bahwa tidak berpengaruh variabel independen beban pajak tangguhan $\left(\mathrm{X}_{2}\right)$ signifikan terhadap variabel dependen manajemen laba (Y) pada perusahaan manufaktur sektor industri barang dan konsumsi yang terdaftar di Bursa Efek Indonesia (BEI) periode tahun 20142018.

4. Berdasarkan hasil uji $\mathrm{t}$ atau secara parsial, dari variabel tax planning terhadap manajemen laba diketahui nilai $\mathrm{t}$ hitung $>\mathrm{t}_{\text {tabel }}$ atau $(3,781>$ $2,01174)$ hal ini diperkuat dengan nilai probability signifikansi $(0,000<0,05)$ artinya berpengaruh atau diterima. Untuk itu hipotesis ketiga (H4) yang menyatakan bahwa berpengaruh variabel independen tax planning (X3) signifikan terhadap variabel dependen manajemen laba (Y) pada perusahaan manufaktur sektor industri barang dan konsumsi yang terdaftar di Bursa Efek Indonesia (BEI) periode tahun 20142018 .

\section{Keterbatasan Penelitian}

Penelitian ini mengandung keterbatasan sebagai berikut :

1. Sampel yang digunakan dalam penelitian ini terbatas hanya berdasarkan perusahaan manufaktur sektor industri dan barang konsumsi, sementara masih banyak sektor lain yang dapat diteliti yaitu sektor pertanian, sektor pertambangan, industri dasar dan kimia, properti, dan lain-lain.

2. Periode sampel dalam penelitian ini hanya dilakukan selama 5 (lima) periode tahun periode tahun 2014-2018, sehingga berpotensi tidak tertangkapnya gambaran yang sebenarnya atas pengaruh corporate social responsibility, beban pajak tangguhan dan tax planning terhadap manajemen laba.

3. Variabel independen yang digunakan dalam penelitian ini hanya 3 yaitu corporate social responsibility, beban pajak tangguhan dan tax planning untuk memengaruhi manajemen laba. Sementara masih banyak variabel lain yang dapat mempengaruhi manajemen laba antara lain yaitu niai perusahaan, ukuran perusahaan, profitabilitas dan lain-lain.

4. Penulis dalam penelitian ini menggunakan proksi DAit (Discretionary accrual) untuk mengukur tingkat manajemen laba. 5.

\section{Saran}

Berikut saran-saran yang dapat diberikan untuk peneliti selanjutnya, adalah sebagai berikut:

1. Bagi peneliti selanjutnya diharapkan agar menggunakan sektor atau industri yang lain yang terdaftar di bursa efek indonesia dengan sempel yang lebih banyak sehingga mampu memperkuat hasil penelitian selanjutnya.

2. Bagi peneliti selanjutnya diharapkan dapat menambahkan periode untuk penelitian yang baru sehingga dapat menghasilkan penelitian yang lebih reprentatif.

3. Bagi peneliti selanjutnya diharapkan menambahkan variabel independen yang lain agar dapat mempengaruhi variabel dependen yaitu manajemen laba selain yang digunakan dalam variabel penelitian ini.

4. Bagi peneliti selanjutnya diharapkan dapat menggunakan proksi-proksi yang berbeda dalam setiap variabel, sehingga hasilnya dapat dibandingkan dengan proksi yang digunakan dalam penelitian ini.

\section{DAFTAR PUSTAKA}

A.A Gede Raka Plasa Negara \& I.D.G Dharma Suputra. (2017). Pengaruh 
Perencanaan Pajak dan Beban Pajak Tangguhan Terhadap Manajemen Laba. ISSN: 2302-8556 E-Jurnal Akuntansi Universitas Udayana Vol.20.3. September (2017): 204520722045.

Andrean, D. (2018). Pengaruh Manajemen Laba, Corporate Governance, dan Financial Leverage Terhadap Agresivitas Pajak (Bachelor's thesis).

Atika Duwi Wulandari. (2018). Pengaruh

Beban Pajak Tangguhan dan Beban Pajak kini Terhadap Earnings Management dengan Komponen Akrual Sebagai Variabel Moderasi Pemoderasi (Studi Empiris Pada Perusahaan Manufaktur yang Terdaftar di Bursa Efek Indonesia Tahun 2013-2015). Jurnal Online Mahasiswa Fakultas Ekonomi Universitas Pamulang.

Budi Setyawan \& Harnovinsah. (2016). Pengaruh Beban Pajak Tangguhan, Profitabilitas, dan Perencanaan Pajak Terhadap Manajemen Laba.

Christina R.S. (2016). Pengaruh Beban

Pajak Tangguhan dan Perencanaan Pajak Terhadap Manajemen Laba. Jurnal Akuntansi volume 6 No.2.

Dea Savitri Ayu Lestari, Ia Kurnia \& Yuniati. (2018). Pengaruh Perencanaan Pajak dan Ukuran Perusahaan Terhadap Manajemen Laba (Studi Empiris Pada Perusahaan Manufaktur yang Terdaftar di Bursa Efek Indonesia Tahun 2015-2017). Jurnal Ilmiah MEA (Manajemen, Ekonomi dan Akuntansi) STIE Muhammadiyah Bandung, Volume 2 No.3.

Debby Tiurmauli. (2017). Pengaruh Beban Pajak Tangguhan dan Perencanaan Pajak Terhadap Praktik Manajemen Laba dengan Variabel Moderasi Corporate Governance (Studi Empiris Pada Perusahaan Manufaktur yang Terdaftar di Bursa Efek Indonesia Tahun 2012-2016).
Dewa Ketut Wira Santana \& Made Gede Wirakusuma. (2016). Pengaruh Perencanaan Pajak, Kepemilikan Manajerial dan Ukuran Perusahaan Terhadap Praktek Manajemen Laba. ISSN: 2302-8559 E-Jurnal Akuntansi Universitas Udayana.14.3 (2016) Hal: 15551583.

Dewi Kusuma Wardani \& Desifa Kurnia Santi. (2018). Pengaruh Tax Planning, Ukuran Perusahaan, Corporate Social Responsibility (CSR) Terhadap Manajemen Laba. Jurnal Akuntansi Vol. 6 No.1 Juni (2018). Universitas Sarjanawiyata Tamansiswa Yogyakarta

Diana Stefani. (2019). Pengaruh Konservatisme dan Perencanaan Pajak Terhadap Manajemen Laba dengan Profitabilitas Sebagai Pemoderasi (Studi Empiris Pada Perusahaan Manufaktur yang Terdaftar di Bursa Efek Indonesia Tahun 2014-2017). Jurnal Online Mahasiswa Fakultas Ekonomi Universitas Pamulang.

Fatimatu Cahya Ningsih. (2017). Pengaruh Aset Pajak Tangguhan, Beban Pajak Tangguhan dan Perencanaan Pajak Terhadap Manajemen Laba. Skripsi Universitas Muhammadiyah Surakarta.

Fitria Rachmadina. (2016). Pengaruh Beban Pajak Tangguhan dan Akrual Terhadap Indikasi Adanya Praktik Manajemen Laba. Skripsi. Universitas Pamulang.

Fransiska Nicolata Daniela. (2018). Pengaruh Beban Pajak Tangguhan, Pajak Kini dan Akrual Terhadap Manajemen Laba. Pemoderasi (Studi Empiris Pada Perusahaan Manufaktur yang Terdaftar di Bursa Efek Indonesia Tahun 2012-2017). Jurnal Online Mahasiswa Fakultas Ekonomi Universitas Pamulang.

Ghafara Mawaridi M.T. (2015) Pengaruh Beban Pajak Tangguhan Terhadap Manajemen Laba. (Studi Empiris 
Pada Perusahaan Manufaktur yang Terdaftar di BEI). Skripsi. Fakultas Ekonomi dan Bisnis Universitas Diponogoro Semarang.

Ghifari, R., \& Sugeng, B. (2018). Pengaruh Profitabilitas dan Pengungkapan Corporate Social Responsibility terhadap Agresivitas Pajak (Studi Pada Perusahaan Pertambangan yang Terdaftar di Bursa Efek Indonesia Periode 2013-2017). (Doctoral dissertation, Perpustakaan Fakultas Ekonomi dan Bisnis Unpas Bandung).

Ghozali, Imam. (2016). Aplikasi Analisis Multivariete Dengan Program IBM SPSS

23 (Edisi 8). Cetakan ke VIII.

Semarang : Badan Penerbit Universitas Diponegoro.

Husnul, N. R. I., \& Retnawati, H. (2017). Manajemen kelas dalam pembelajaran matematika di SMA Negeri Yogyakarta. Jurnal Akuntabilitas Manajemen Pendidikan, 5(2), 189-198.

Ilham Sentosa. (2019). Pengaruh Tax Planning dan Corporate Social Responsibility Terhadap Manajemen Laba Pada Perusahaan Manufaktur yang Terdaftar di BEI Tahun 20122016. Skripsi, Fakultas Ekonomi Universitas Medan Area.

Irsan L \& Suryani. (2018). Pengaruh Tax Planning, Beban Pajak Tangguhan dan Ukuran Perusahaan Terhadap Manajemen Laba. (Studi Empiris Pada Perusahaan Industri Barang Konsumsi di Bursa Efek Indonesia Tahun 2012-2016). Jurnal Akuntansi dan Keuangan FEB Universitas Budi Luhur.

Kementrian Lingkungan Hidup. (2011). Pedoman CSR Bidang Lingkungan.

Kurnia Dwi Priyatma \& Holiawati. (2015) Pengaruh Good Corporate Governance, Ukuran Perusahaan, dan Leverage Terhadap Manajemen Laba (Studi Empiris Pada Sektor Perbankan Yang Terdaftar DI BEI Tahun 2010
- 2013). Jurnal Ilmiah Akuntansi Universitas Pamulang, 3 (1). pp. 664-691. ISSN 2339-086

Kuznetsov, A., Kuznetsova, O., \& Warren, R. (2009). CSR and the legitimacy of business in transition economies:

The case of Russia. Scandinavian Journal of Management, 25(1), 37-

45.

Luayyi, S. (2012). Teori Keagenan dan Manajemen Laba dari Sudut Pandang Etika Manajer. El Muhasaba: Jurnal Akuntansi, 1(2).

Lucy Citra Fitriany (2016). Pengaruh Aset Pajak Tangguhan, Beban Pajak Tangguhan dan Perencanaan Pajak Terhadap Manajemen Laba. EJurnal Akuntansi Universitas Riau JOM Fekon Vol.3 No.1 (Februari) 2016.

Luayyi, S. (2012). Teori keagenan dan manajemen laba dari sudut pandang etika manajer. El Muhasaba: Jurnal Akuntansi, 1(2).

Mochammad Irfaqi. (2018). Pengaruh Perencanaan Pajak, Adopsi IFRS, dan Resiko Litigasi Terhadap Manajemen Laba (Studi Empiris Pada Perusahaan Manufaktur yang Terdaftar di Bursa Efek Indonesia tahun 2012-2016) Jurnal Online Mahasiswa Fakultas Ekonomi Universitas Pamulang.

Resmi, Siti. (2017). Perpajakan Teori \& Kasus Edisi 10 Buku 1. Jakarta: Selembar Empat.

Santoso, Singgih. (2010). Statistik Parametik, Konsep dan Aplikasi dengan SPSS. Cetak Pertama, PT Elex Media Komputindo, Jakarta, PT Gramedia.

Suaryana, A. (2011). Implementasi akuntansi sosial dan lingkungan di Indonesia. Jurnal Ilmiah Akuntansi dan Bisnis.

Sugiyono. (2017). Metode Penelitian Kuantitatif Kualitatif dan $R \& D$. Bandung : Alfabeta.

Tiara Timuriana \& Rezwan Rizki Muhamad. (2015). Pengaruh Aset Pajak 
Tangguhan dan Beban Pajak Tangguhan Terhadap Manajemen Laba. JIAFE (Jurnal Ilmiah Akuntansi Fakultas Ekonomi) Volume 1 No.2. Universitas Pakuan. Winty Dian Natalia. (2019). Pengaruh Tax Planning, Ukuran Perusahaan dan Leverage Terhadap Manajemen Laba Laba (Studi Empiris Pada Perusahaan Manufaktur yang Terdaftar di Bursa Efek Indonesia tahun 2015-2017). Skripsi, Fakultas Ekonomi dan Bisnis Universitas Muhammadiyah Surakarta.

Yunita, N. (2018). Pengaruh biaya hutang dan corporate social responsibility terhadap penghindaran pajak (studi empiris pada perusahaan manufaktur sektor industri barang konsumsi yang terdaftar di bei tahun 2013-2017). 